Case report

\title{
Pre-labor silent rupture of unscarred uterus at 32 weeks with intact amniotic sac extrusion: a case report Ritu Rana ${ }^{*}$ and Manju Puri ${ }^{2}$
}

\author{
Addresses: ${ }^{1}$ Department of Obstetrics \& Gynecology, Princess Alexandra Hospital, Harlow, Essex, CM20 1QX, UK \\ ${ }^{2}$ Department of Obstetrics \& Gynecology, Lady Hardinge Medical College and Smt Sucheta Kriplani Hospital, New Delhi 110001 , India \\ Email: RR* - riturana2003@yahoo.com; MP - purimanju@rediffmail.com \\ * Corresponding author
}

Received: 7 April 2009 Accepted: 24 June 2009 Published: 16 July 2009

Cases Journal 2009, 2:7095 doi: 10.4076/1757-1626-2-7095

This article is available from: http://casesjournal.com/casesjournal/article/view/7095

(C) 2009 Rana and Puri; licensee Cases Network Ltd.

This is an Open Access article distributed under the terms of the Creative Commons Attribution License (http://creativecommons.org/licenses/by/3.0), which permits unrestricted use, distribution, and reproduction in any medium, provided the original work is properly cited.

\begin{abstract}
Introduction: Spontaneous rupture of uterus in unscarred uterus prior to onset of labor in third trimester is extremely rare and to our knowledge, very few cases have been reported so far.

Case presentation: A 26-year-old third gravida women with 32 weeks pregnancy presented with pre-labor rupture uterus with extrusion of intact amniotic sac from the rent in uterine fundus.

Conclusion: Rupture uterus can present in third trimester even before labor and should be kept in differential diagnosis of pregnancy with abdominal pain of any degree with fetal demise.
\end{abstract}

\section{Introduction}

Spontaneous rupture of uterus has been reported many times in pregnant women mainly during labor, due to external injuries and in scarred uterus. However, spontaneous rupture in unscarred uterus prior to onset of labor in third trimester is extremely rare [1-3].

\section{Case presentation}

A 26-year-old pregnant women of Asian Indian origin was referred to the obstetric casualty by the general practitioner with a provisional diagnosis of placental abruption in view of abdominal pain, pallor and inability to find fetal heart. The women had insidious onset of pain for $12 \mathrm{hrs,}$ and with reduced fetal movements for the same duration. The woman was third gravida with 32 weeks gestation, with previous two normal deliveries and an uneventful antenatal period. Her dating and anomaly scan were normal. There was also no history of trauma, any diagnostic or therapeutic intrauterine intervention, vaginal bleeding or labor pains. She had no significant past medical, surgical history or gynecological history.

On examination, she was pale with respiratory rate of 28 per minute, pulse rate of 110 per minute and blood pressure of 90/60 mmHg. On abdominal examination, uterus measured 30 weeks, with mild abdominal tenderness and no increased tone. The uterine wall felt thin but with regular outline and no fetal part was palpable. Fetal heart could not be localized. Speculum examination showed no vaginal bleeding and there was marked tenderness on internal examination and cervix was uneffaced and os admitted tip of finger. 
Ultrasound scan revealed fetal demise. An intact amniotic sac with fetus and normal volume of amniotic fluid, without any echogenecity to suggest blood, was seen lying outside the uterus. Uterus was deviated towards left iliac fossa. Diagnosis of rupture uterus with fetal demise was made and the woman was prepared for laparotomy. Blood investigations revealed hemoglobin of $7.7 \mathrm{gm} \%$ with no evidence of coagulopathy.

After resuscitation with intravenous fluids, the patient was taken for surgery. Emergency exploratory laparotomy was done with consent for hysterectomy or uterine repair with tubal sterilization under intravenous antibiotic cover. An intact amniotic sac with fetus was found along with 1.5 liter of haemoperitoneum. Membranes were ruptured and male stillborn fetus (weight 2.2 kilograms) was delivered with breech extraction. The amniotic fluid was clear, and placenta was lying outside the uterus and appeared complete and normal. There was a 3 inch tear on the right side of the uterine fundus, $2 \mathrm{~cm}$ anterior to the cornua. The myometrium adjacent to this was relatively thin. There was no evidence of couvelier uterus. The tear was repaired by suturing the uterus in double layer. Bilateral tubal ligation was done. She received one unit of blood during intra-operative and three during the postoperative period. Her postoperative period was uneventful and was discharged after eight days.

\section{Discussion}

Rupture of unscarred uterus is a rare event involving 1:16,000 deliveries [4]. The probable causes in reported cases are external injuries, induction of labor, high birth order, cephalo-pelvic disproportion, placenta accreta, fundal pressure, abruption, cocaine abuse and history of intrauterine intervention causing perforation [5-9].

To our knowledge, this is the fourth reported case of pre-labor silent rupture uterus in third trimester in an unscarred uterus. In one of the reported cases, rupture uterus was found behind the cornual structures and was diagnosed on laparotomy done for deteriorating maternal condition after vaginal delivery of the stillborn baby by forceps [1]. The second reported case had a tear above the insertion of right uterosacral ligament and the baby was born by emergency lower segment Caesarean section [2]. The third case reported posterior uterine wall tear diagnosed on laparotomy done for post failed induction for deteriorating maternal condition and fetal demise [3].

Apart from pre-labor uterine rupture in an unscarred uterus, this case had a subacute onset. The fetus along with the amniotic sac had silently extruded through the rent in uterus making the diagnosis of rupture uterus difficult clinically, as uterine contour was falsely preserved due to intact amniotic sac. There was no placenta accreta, couvelaire uterus, any signs of placental abruption or history of connective tissue disorder like Ehler Danlos syndrome [9]. It thus makes us speculate that this rupture could have been due to some inherent weakening in the uterine myometrium, which became more profound in third pregnancy due to repeated stretching from previous pregnancies.

\section{Conclusion}

This case re-emphasizes that rupture uterus can present in many different ways and high suspicion is required for timely intervention to prevent maternal morbidity and mortality.

\section{Consent}

Written informed consent was obtained from the patient for publication of this case report and accompanying images. A copy of the written consent is available for review by the Editor-in-Chief of this journal.

\section{Competing interests}

The authors declare that they have no competing interests

\section{Authors' contributions}

The case was attended by RR and operated by MP and RR. RR assisted and analyzed the case, conducted the literature search and review for analysis. She prepared the first draft of the report. MP, supervised and guided on development of manuscript. All authors read and approved the final manuscript.

\section{References}

I. Abbi M, Misra R: Rupture of uterus in primigravida prior to onset of labor. Int J Fertil Womens Med 1997, 42:4I8-420.

2. Langton J, Fishwick K, Kumar B, Nwosu EC: Spontaneous rupture of an unscarred gravid uterus at 32 weeks gestation. Human Rep 1997, I I 2:2066-2067.

3. Walsh CAMB, O'Sullivan RJ, Foley ME: Unexplained prelabor uterine rupture in a term primigravida. Obstet Gynecol 2006, 1 08:725-727.

4. Miller DA, Paul RH: Rupture of the unscarred uterus. Am J Obstet Gynecol 1996, I 74:345.

5. Turner MJ: Uterine rupture. Best Pract Res Clin Obstet Gynaecol 2002, 1 6:69-79.

6. Imseisss HM, Murtha AP, Alexander KA, Barnett BD: Spontaneous rupture of primigravidae uterus secondary to Placenta Percreta. J Reprod Med 1998, 43:233-236.

7. Schrinsky DC, Benson RC: Rupture of pregnant uterus: a review. Obstet Gynecol Surv 1978, 33:217-232.

8. Gonsoulin W, Borge D, Moise KJ Jr: Rupture of unscarred uterus in primigravid woman in association with cocaine abuse. $\mathrm{Am} J$ Obstet Gynecol 1990, 163:526-527.

9. Gelbmann CM, Kollinger M, Gmeinwieser J, Leser HG, Holstege A, Scholmerich J: Spontaneous rupture of liver in a patient with Ehlers Danlos disease type IV. Dig Dis Sci 1997, 42:I724-I730. 